Info Artikel

Diterima : 27 Maret 2020

Disetujui : 01 Juli 2020

Dipublikasikan : 20 Juli 2020

\title{
Kajian Pemerolehan Bahasa pada Anak Usia Tiga Puluh Enam Bulan
}

\author{
Zoni Sulaiman ${ }^{1 凶}$ \\ ${ }^{1}$ Institut Pendidikan Indonesia (IPI), Garut \\ 1zoni@institutpendidikan.ac.id
}

Abstract: The language Acquisition in early childhood is a golden period that determines the development of children's psychology. Many parents do not know the language acquisition barriers that might occur to their children, so that language acquisition barriers are not addressed early on. Therefore, the researcher is interested in conducting research on language acquisition in children aged 36 months. This study aims to determine language acquisition in the field of phonology and the Mean Length of Utterance in children. This research employed a descriptive method with qualitative analysis techniques. The subject in this study was a female child aged 36 months. Data collection is done by documentation technique. The results showed that the acquisition of phonological level language in the subject of the study still occurred on fluency or pronunciation errors in the form of phoneme replacement and phoneme obsession at the beginning and end of syllables. The obstacles in language acquisition were mostly caused by environment and family. The Mean Length of Utterance is 2.75, which is at level 6, one level lower than children in her age.

Keywords: children, language acquisition, study, fonology

Abstrak : Pemerolehan bahasa pada anak usia dini merupakan masa emas yang sangat menentukan perkembangan psikologi anak. Orang tua banyak yang tidak mengetahui hambatan pemerolehan bahasa yang mungkin terjadi pada anaknya sehingga hambatan pemerolehan bahasa tidak ditangani sejak dini. Oleh karena itu, penelitian tentang pemerolehan bahasa pada anak usia 36 bulan sangat menarik untuk dilakukan. Penelitian ini bertujuan untuk mengetahui pemerolehan bahasa anak pada tataran fonologi dan rata-rata panjang ujaran pada anak. Penelitian ini menggunakan metode deskriptif dengan teknik analisis kualitatif. Subjek penelitiannya adalah seorang anak perempuan berusia 36 bulan. Pengumpulan data dilakukan dengan teknik dokumentasi. Hasil penelitian menunjukkan bahwa pemerolehan bahasa tataran fonologi pada subjek penelitian masih terjadi ketidakfasihan atau kesalahan pelafalan berupa penggantian fonem dan pelesapan fonem pada awal dan akhir suku kata. Hambatan pemerolehan bahasa ini lebih disebabkan oleh faktor lingkungan keluarga. Rata-rata panjang ujaran 2,75 , berada pada level 6 , satu level lebih rendah dari anak seusianya.

Kata Kunci : anak, kajian, pemerolehan bahasa, fonologi

Sitasi Artikel:

Sulaiman, Z. (2020). Kajian Pemerolehan Bahasa pada Anak Usia Tiga Puluh Enam Bulan. Disastra: Jurnal Pendidikan Bahasa dan Sastra Indonesia, 2(2), 110-115. doi:http://dx.doi.org/10.29300/disastra.v2i2.2968 


\section{Pendahuluan}

Pemerolehan bahasa pada anak merupakan bagian dari perkembangan psikologis yang perlu mendapatkan perhatian serius. Anak yang memiliki hambatan berbicara atau ketidakmampuan pengucapan kata seperti lazimnya kemampuan anak seusianya sering diperolok di lingkungannya. Perlakuan tersebut dapat menyebabkan anak tidak percaya diri sehingga perkembangan psikologisnya terganggu. Jika tidak ditangani secara serius, hambatan ini akan berlanjut menjadi hambatan belajar, hambatan berkomunikasi dengan lingkungan, bahkan sampai hambatan psikologis yang lebih berat pada usia dewasa. Hal ini sesuai teori yang menyatakan bahwa kesulitan atau hambatan pemerolehan bahasa pada anak berusia di bawah lima tahun dapat menyebabkan hambatan dalam kemampuan belajar pada berbagai aspek (Madyawati, 2013).

Pemerolehan bahasa pada anak sangat dipengaruhi oleh lingkungan tempat tinggal anak tersebut karena anak akan merekam setiap bahasa yang digunakan di lingkungannya kemudian menjadikannya bagian dari pengalaman berbahasa. Hal ini menjadikan lingkungan anak sangat mendukung pemerolehan bahasa sehingga anak tersebut akan memiliki kemampuan berbahasa yang ideal. Fatmawati (2015) menyatakan bahwa jika orang di lingkungannya menggunakan kosakata yang salah, maka anak bukan hanya akan mengikuti, tetapi mempelajari dan menerapkan sebagai konsep dalam proses pemerolehan bahasannya. Suardi (2019) juga menyatakan bahwa secara alamiah pemerolehan bahasa anak dapat dilakukan dengan cara berkomunikasi dengan orang di lingkungan sekitarnya. Lingkungan yang paling mempengaruhi pemerolehan bahasa anak adalah lingkungan terdekat, yakni keluarga. Dalam hal ini orang tua memiliki pengarauh yang sangat kuat dalam pemerolehan bahasa anak karena menjadi acuan awal bagi anak dalam pemerolehan bahasanya.

Sepanjang pengamatan penulis di lapangan, masih banyak orang tua yang belum memperhatikan perkembangan pemerolehan bahasa anaknya secara intensif. Mereka cenderung membiarkan pemerolehan bahasa anaknya berlangsung tanpa control dan apabila anak melakukan kesalahan cenderung dibiarkan. Hal ini menyebabkan kesalahan tersebut berlangsung terus-menerus sehingga menjadi hambatan dalam pemerolehan bahasa karena banyak orang tua yang tidak memahami bahwa pada perkembangan bahasa tahap awal anak harus mendapatkan bimbingan khusus dari orang tua sebagai bagian dari lingkungan terdekatnya. Anak pada rentang usia 0 s.d. 5 tahun harus mendapat perhatian khusus (Nurjamiaty, 2015). Bahkan hasil penelitian tentang pemerolehan bahasa kedua di Inggris menemukan bahwa penggunaan bahasa Inggris dengan teman, pendidikan orang tua sangat menentukan keterampilan kognitif yang akan berkontribusi penuh terhadap berbagai kemungkinan dalam penguasaan bahasa (Soto-corominas, 2020).

Selama kegiatan pengamatan prapenelitian terhadap calon subjek penelitian di lingkungannya, peneliti menangkap gejala pemerolehan bahasa pada tataran fonologi yang di bawah standar. Peneliti menangkap ketidakmampuan pengucapan beberapa kata pada subjeksubjek penelitian. Selain itu, terdapat 
kecenderungan kurangya perhatian orang tua terhadap pemerolehan bahasa anaknya dikarenakan kesibukan dalam pekerjaan. Berdasarkan hasil observasi tersebut, maka peneliti melakukan penelitian dengan judul "Kajian Pemerolehan Bahasa pada Anak Usia 36 Bulan". Penelitian ini bertujuan untuk mengetahui pemerolehan bahasa pada tataran fonologi, rata-rata panjang ujaran pada anak usia 36 bulan, serta penyebab hambatan pemerolehan bahasa pada anak.

Peneliti melakukan penelitian pemerolehan bahasa tataran fonologi karena kemampuan berbahasa yang paling mendasar bagi anak adalah tataran fonologi. Perkembangan pemerolehan bahasa tataran fonologi merupakan perkembangan linguistik pertama yang dilalui anak (Qalbi, 2020). Penelitian serupa telah dilakukan oleh Yanti (2016) dengan subjek penelitian anak berusia 2430 bulan. Hasil penelitian di antaranya menemukan bahwa berbagai variasi pemerolehan fonologi disebabkan belum sempurnanya alat ucap dan juga stimulus yang diberikan oleh lingkungan.

\section{Metode Penelitian}

Penelitian ini menggunakan metode deskriptif dengan teknik analisis kualitatif. Penggunaan metode ini disesuaikan dengan karakteristik penelitian yang akan menggambarkan gejala yang terjadi pada subjek penelitian secara sistematis. Subjek penelitian adalah seorang anak perempuan bernama Azkia Nabila berusia tiga puluh enam bulan, tinggal di Desa Mekarsari Kecamatan Cilawu Kabupaten Garut. Kedua orang tuanya bekerja sebagai pedagang di pasar. Teknik pengumpulan data dilakukan dengan teknik dokumentasi, yaitu dengan cara merekam tuturan anak kemudian mentranskripsikan agar mudah untuk dianalisis. Perekaman data dilakukan secara alami (peneliti tidak memberikan stimulus kepada subjek penelitian). Untuk mengetahui rata-rata panjang ujaran, pengolahan data dilakukan menggunakan rumus MLU dengan beberapa tahap. Pertama mengambil sampel sebanyak 100 ujaran, kedua menghitung jumlah morfem, dan ketiga membagi jumlah morfem dengan jumlah ujaran.

\section{Hasil dan Pembahasan}

Hasil penelitian menunjukkan adanya ketidakfasihan pengucapan pada subjek penelitian. Terdapat beberapa ujaran yang menghilangkan beberapa fonem. Data yang terkumpul akan diolah untuk mengetahui pemerolehan bahasa tataran fonologi dan rerata panjang ujaran.

Pertama, dari segi pemerolehan bunyi atau kajian fonologi, bunyi vokal maupun konsonan yang diperoleh anak diujarkan secara bergantian atau berurutan secara alami. Beberapa contoh pengucapan kata oleh subjek penelitian yang akan diolah dalam penelitian ini disajikan dalam tabel berikut ini.

Tabel 1. Data Pemerolehan Fonologi

\begin{tabular}{lll}
\hline No. & Kata & Pengucapan \\
\hline 1. & Warna & Walna \\
2. & Siram & Silam \\
3 & Baru & Bayu \\
4. & Motor & Motol \\
5. & Nyebor & Nyebol \\
6. & Bangor & Bangol \\
7. & Lauk & Auk \\
8. & Alim & Aim \\
9. & Jauh & Auh \\
10. & Galak & Alak \\
\hline
\end{tabular}


Contoh kata dalam tabel tersebut menunjukan dua jenis kesalahan dalam pelafalan, yakni penggantian fonem dan pelesapan bunyi fonem. Kesalahan pengucapan bunyi fonem [r] ada yang di awal suku kata, contoh pada kata 'silam' seharusnya 'siram', dan di akhir suku kata, contoh pada kata 'motol' seharusnya 'motor'. Pelesapan bunyi konsonan [1] dan [j] di awal suku kata contoh pada kata 'auk' seharusnya 'lauk' dan kata 'auh' seharusnya 'jauh'.

Dalam penelitian ini selain didapatkan hasil analisis pergantian dan pelesapan fonem pada awal suku kata dan akhir suku kata, juga didapatkan data terjadinya ketidakkonsistenan penggantian bunyi fonem [r] pada subjek penelitian, yakni tidak semua dilafalkan menjadi bunyi fonem [1]. Pada kata 'baru' menjadi 'bayu', bunyi [r] dilafalkan menjadi bunyi [y]. Hal tersebut menunjukkan bahwa kesalahan pelafalan tidak hanya disebabkan oleh ketidakmampuan atau keterbatasan alat ucap semata, tetapi berhubungan dengan kebiasaan. Jika dihubungkan dengan observasi singkat peneliti terhadap lingkungan anak, hal itu berkaitan dengan pembiasaan oleh orang di sekitarnya. Ketika subjek melakukan kesalahan pelafalan, orang tuanya justru ikut melafalkan seperti kesalahan tersebut sehingga anak tidak merasa melakukan kesalahan pelafalan. Hal tersebut membuat subjek melakukan kesalahan berulang dan menjadi sebuah kebiasaan. Kebiasaan positif akan menjadi input untuk penguatan positif dan kebiasaan negatif akan menjadi input penguatan negatif dalam pemerolehan bahasa anak (Arsanti, 2014). Hasil penelitian ini sejalan dengan penelitian (Sebayang, 2018) dan (Johan, 2019), yang menyatakan bahwa hasil penelitiannya menunjukkan bahwa morfem-morfem yang dihasilkan respondennya berada dalam bentuk pergantian dan pelesapan fonem.

Selanjutnya akan disajikan data penelitian untuk menentukan rata-rata panjang ujaran. Hasil transkripsi data yang diambil sebanyak seratus tuturan. Dari data tersebut diambil beberapa contoh yang dianggap mewakili, lalu disajikan dalam tabel berikut ini.

Tabel 2. Contoh Kata per Kalimat

\begin{tabular}{llc}
\hline No & Tuturan & $\begin{array}{c}\text { Jumlah } \\
\text { Kata }\end{array}$ \\
\hline 1 & Uih & 1 \\
2 & Cicing & 1 \\
3 & Hoyong eta & 2 \\
4 & Engal atu mamah & 3 \\
5 & Tong bangor atuh & 3 \\
6 & Itu ucing watil & 3 \\
7 & Mamah meuni kitu wae & 4 \\
8 & Dibejaan ulah teh nya & 4 \\
9 & Ali eta nu saha mah? & 5 \\
10 & Engal atu mamah meuni & 5 \\
& naha & \\
\hline
\end{tabular}

Data pada tabel 2 tersebut menunjukkan bahwa kalimat yang diucapkan terdiri atas 1 s.d. 5 kata per kalimat. Untuk menghitung MLU data konkret jumlah kata pada 100 tuturan yang sudah direkam dan ditranskripsikan akan disajikan dalam tabel lalu dihitung dengan rumus MLU.

Tabel 3. Jumlah kata per kalimat

\begin{tabular}{lcc}
\hline $\begin{array}{l}\text { Jumlah Kata Per } \\
\text { Tuturan }\end{array}$ & $\begin{array}{c}\text { Jumlah } \\
\text { Tuturan }\end{array}$ & $\begin{array}{l}\text { Jumlah } \\
\text { Morfem }\end{array}$ \\
\hline Kalimat satu kata & 14 & 14 \\
Kalimat dua kata & 27 & 54 \\
Kalimat tiga kata & 36 & 108 \\
Kalimat empat kata & 16 & 64 \\
Kalimat lima kata & 7 & 35 \\
\hline Jumlah & $\mathbf{1 0 0}$ & $\mathbf{2 7 5}$ \\
\hline
\end{tabular}


$M L U=\begin{array}{cc}\text { Jumlah morfem } & 275 \\ \text { Jumlah tuturan } & 100\end{array}$

$M L U=2,75$

Rata-rata panjang ujaran pada subjek penelitian 2,75. Berdasarkan teori MLU yang dikemukakan Brown, anak usia tiga tahun panjang ujarannya ada pada tahap 7 dengan rentang 3,0 - 3,5. Hal ini menunjukkan bahwa panjang ujaran subjek penelitian berada satu level di bawah MLU rata-rata anak seusianya. Jika dihubungkan dengan hasil pengamatan singkat peneliti terhadap pola komunikasi lingkungan memang kurang baik. Kedua orang tuanya jarang berkomunikasi antara keduanya maupun dengan subjek penelitian karena sibuk dengan pekerjaannya. Mereka hanya berkomunikasi seperlunya. Hal ini memungkinkan untuk diikuti oleh subjek penelitian sehingga rata-rata panjang ujaranya di bawah MLU. Hasil penelitian ini mendukung hasil penelitian lain bahwa anak yang mendapatkan sedikit input sebagai stimulus dari lingkungan akan mengalami penundaan atau perlambatan dalam perkembangan pemerolehan bahasanya (Narafshan, 2014).

$$
\text { Hasil penelitian lainnya }
$$

menunjukkan adanya pengaruh lingkungan terhadap pemerolehan bahasa bidang fonologis dan morfologi pada subjek penelitian. Pemerolehan bahasa anak dipengaruhi oleh lingkunganya, terutama interaksi sosial dengan anggota keluarga dan masyarakat (Surbakti, 2017). Hal ini sejalan dengan pernyataan bahwa Lingkungan yang mendukung tumbuh kembang bahasa anak memberi pengaruh yang sangat signifikan terhadap kemampuan bahasa anak, maka dari itu anak harus mendapatkan contoh dan model, stimulus dan respon dari lingkungannya agar pemerolehan bahasanya memadai (Yusuf, 2016).

\section{Simpulan}

Dari hasil pengolahan data dan pembahasan yang sudah dipaparkan dapat diambil beberapa simpulan penelitian. Pemerolehan bahasa anak yang menjadi subjek penelitian pada tataran fonologi masih melakukan penggantian dan pelesapan fonem pada awal dan akhir suku kata serta terdapat beberapa ketidakkonsistenan dalam pergantian fonem yang dilafalkan. Rata-rata panjang ujaran (Mean Length of Utterance) 2,75 ( kategori level 6), satu tingkat lebih rendah dari anak sesusianya. Kesalahan pelafalan dan keterbatasan rata-rata penjang ujaran dipengaruhi oleh faktor lingkungan keluarga yang melakukan pembiaran dan kurang memperhatikan pemerolehan bahasa anak.

\section{Daftar Pustaka}

Arsanti, M. (2014) Pemerolehan bahasa pada anak (kajian psikolinguistik). J. PBSI, 3 (2), 24-47

Fatmawati, S. R. (2015). Pemerolehan bahasa pertama anak menurut tinjauan psikolinguistik. J. Lentera, $18(1), 63-75$

Johan, M, \& Suri, S. R. Speech disorder for the children under three years old: the study of neurolinguistics. J. Gramatika, 5 (2), 25-35

Madyawati, L. (2013). Mengoptimalkan word acquisition pada anak melalui bercerita menggunakan wayang kardus (penelitian di kota magelang dan kabupaten Magelang). J. Tarbiyatunna, 4 (1), 225-235 
Volume 2, Nomor 2, Juli 2020 ISSN 2655-3031 (P), 2655-7851 (O)

Nurafshan, M. H., Sadighi, F., Bagheri, M. S., \& Shokrpour, N. (2014). The Role of Input in First Language Acquisition. J. International Journal of Applied Linguistics \& English Literature, 3 (1), 86-91

Nurjamiaty. (2015). Pemerolehan bahasa anak usia tiga tahun berdasarkan tontonan kesukaannya ditinjau dari kontruksi semantik. J. Kultura, 42-62

Qalbi, U. S. \& Nuryani. (2020). Jenis kalimat pada tuturan anak usia empat tahun: kajian sintaksis. J. Disastra, 2 (1), 50-56

Sebayang, S. K. H. (2018). Analisis pemerolehan bahasa pertama (bahasa melayu) pada anak usia 3 tahun. J. Pena Indonesia, 4 (1), 105-114

Soto-Corominas, A., Paradis, J., Rusk, B., Marinova-Todd, S., \& Zhang, X. (2020). Oral language profiles of english second language learners in adolescence: cognitive and input factors influence how they compare to their monolingual peers. Cambridge University Press. J. Studies in second language acquisition.1-24. doi:10.1017/S0272263119000767

Suardi, I. P., Syahrul, R., \& Asri, Y. (2019). Pemerolehan bahasa pertama pada anak usia dini. J. Obsesi, 3 (1), 265 273

Surbakti, I. \& Situmorang, K. H. (2017). Acquisition planning and language acquisition by Indonesian four-year old children. J. Macrothink Institute, 9 (3), 152-165

Yanti, P. G. (2016). Pemerolehan bahasa anak: kajian aspek fonologi pada anak usia 2 - 2,5 tahun. J. Visi, 11 (2), 131-141

Yusuf, E. B. (2016). Perkembangan dan pemerolehan bahasa anak. J. Yinyank, 11 (1), 39-60 